\title{
Towards a Pluralist Labor Geography: Constrained grassroots agency and the socio-spatial fix in Dêrsim, Turkey
}

\author{
Celal Cahit Ağar \\ University of Exeter Business School
}

\author{
Steffen Böhm \\ University of Exeter Business School \\ s.boehm@exeter.ac.uk
}

To cite:

Ağar, C. C., \& Böhm, S. (2018). Towards a pluralist labor geography: Constrained grassroots agency and the socio-spatial fix in Dêrsim, Turkey. Environment and Planning A: Economy and Space, 50(6), 1228-1249.

\begin{abstract}
This paper explores the interplay between capital, socio-spatial structure and grassroots agency in the context of the recent trajectories of labor geography. Based on field research conducted in Dêrsim, Turkey, our analysis unfolds the constraining role of socio-spatial structure in the agency and praxis of grassroots movements and their geography-making and crisisdisplacement from below. Through the case study, we propound a concept of socio-spatial fix to explain how this praxis conjoins with and assists capital in both staving off its recurrent crises and reproducing its own logic of accumulation. Our analysis reveals that the socio-spatial fix in Dêrsim, which is constituted by the grassroots struggle against hydroelectric power plant projects, performs three functions. First, it facilitates the production of capitalist social relations and spaces; second, it strengthens and maintains the existing social order through temporally moderating the province's chronic problems; and third, it provides legitimacy for the capitalist exploitation of nature, culture and histories. Our research contributes to the emerging pluralist school of labor geography, providing an empirically substantiated insight into how capital reproduces itself via socio-spatial fixes produced by constrained grassroots agency.
\end{abstract}

\section{Introduction}

Turkish capitalism has recently been defined by a boom of construction projects of all types. In the eastern province of Dêrsim (officially Tunceli), for example, a great number of 
hydro dams have been built over the past twenty years, leading to a range of economic, social and ecological crises (Dissard, 2017; Ronayne, 2005). These recent crises are embedded in a more deep-rooted crisis: the chronic socioeconomic under-development of the region, which has been historically produced by both uneven capitalist development and the Turkish state's assimilation policies targeted at Alevi Kurds. For almost two decades, Dêrsimites from all sorts of classes have been resisting these dam projects, which pose a threat to their survival and selfreproduction as well as reshaping the socio-spatial relations and deepening the existing crises embedded in this underdeveloped geography. Through their anti-dam struggle, Dêrsimites have not only attempted to put the brakes on the dam projects, but have also engaged in the making of new geographies to overcome the crises perpetually produced by Turkish capitalism. However, as we will show in this paper, their praxis has also aided capital's spatial displacement of crisis, enabling it to reproduce its own logic of accumulation.

In examining the nexus of capital, society and space, the question of how the geography of capitalism is made has been the subject of research agendas within critical geography. Many Marxist scholars have explored this question, stressing the formative capacity of capital in producing and shaping capitalist spaces and social relations (Harvey, 2006a; Massey, 1995; Storper and Walker, 1989). The notion of displacement of crisis has emerged as an integral part of the spatial analysis of capitalism, and Harvey's theory of spatial fix (2006a) has been widely employed to explore not only how the geography of capitalism is made, but also how capitalism survives via expansion and restructuring of capital accumulation.

However, the capital-centric approach of this well-established critical literature has been criticized by a group of Marxist geographers due to its conceiving of society in a passive manner, neglecting its role in making the geographies of capitalism (Herod, 1997, 2003; Castree et al., 2004). Consequently, the debate among Marxist geographers has given birth to a sub-discipline, namely labor geography, which focuses on workers' praxis of shaping the economic geography of capitalism. The capital-centric sentiment of spatial fix has also been re-conceptualized within a bottom-up perspective, developing the concept of 'labor's spatial fix' to explain how the landscapes of capitalism are shaped by workers' praxis to overcome their problems of survival and self-reproduction.

Without any doubt, labor geography has played an important role in the development of the critical geography literature, placing emphasis not on society, but on workers' agency. However, the labor geography project has - for a while now - reached a phase of reflection 
and re-evaluation (Peck, 2017). Many critical scholars, including the leading contributors of the field, have debated existing research gaps, underdeveloped/neglected issues and future directions for labor geography (Peck, 2017; Herod, 2012; Coe and Jordhus-Lier, 2011; Bergene et al., 2010; Tufts and Savage, 2009; Castree, 2007; Lier, 2007).

We conceive of labor geography's recent phase of reassessment as a transitional stage, forming an emerging school of thought with an integrative, intersectional and recombinant labor geography approach - what might be called 'pluralist labor geography' (Peck, 2017). In this respect, our paper engages with the following three matters of debate in order to build an empirically substantiated framework, allowing it to contribute to the emerging school of thought. First, we reprise the long-standing criticism of labor geography of confining agency to a worker/union-centrism. We argue that this centrism, which is still prevalent even in more flexible accounts in labor geography, can be transcended by a grassroots agency perspective. Second, the emerging school of thought in labor geography has been characterized by an increasing emphasis on the problem of theorization of agency and structure. In this regard, our paper addresses an expanded notion of socio-spatial structure to reframe the interplay between structure and agency with respect to uneven geographical development. Third, we problematize the traditional notion of labor's spatial fix due to its drawing of a non-dialectical distinction between capital's and labor's spatial fixes, setting one against the other. Rather, we propound a concept of socio-spatial fix, shifting the analytical focus to coalescences between capital's and labor's praxis towards displacement of crisis. That is, despite all their differences, we argue that capital and labor come together to fix crises of capitalist development.

The paper's theoretical argument is substantiated by our empirical analysis of the antidam struggle surrounding the hydroelectric power plant projects in Dêrsim, located in Eastern Turkey. In this case, we analyze the interplay between dam projects, Dêrsim's socio-spatial structure and grassroots agency. Our analysis reveals the role of the socio-spatial structure in constraining the agency and key dynamics of grassroots movements such as confrontations, alliance formation and compositional pattern. We disclose a socio-spatial fix, which has been brought about by the agency of grassroots movements itself. Our analysis shows that this sociospatial fix from below assists capital, performing three functions. First, it facilitates the production of new capitalist social relations and spaces; second, it moderates some of the province's chronic problems; and third, it provides legitimacy for the capitalist exploitation of nature, culture and histories. 


\section{Labor geography and the debate about structure, agency and fixes from below}

The labor geography project represents an important step towards going beyond capitalcentric frames in critical geography, which has generally failed to grasp the potential of labor's agency to make the geography of capitalism. Paraphrasing Herod (1997:3), it paves the way for seeing the making of the economic geography of capitalism through the eyes of labor by focusing on how workers shape the landscape in their own image whilst facilitating their goals.

Although labor geography took shape as a project after the late 1990s, its origin dates back to the period between the 1970s and 1990s, when the industrialized economies had gone through phases of restructuring and social, institutional and regulatory transformations - what has become known as deindustrialization (Peck, 2017). Following this foundational phase and Herod's (1997) influential study, labor geography has emerged as a sub-discipline in the critical geography literature. However, as Peck (2017) argues, after reaching a certain level of maturity in the course of its evolution since the late 1990s, the labor geography project has - for a while now - arrived at a phase of reassessment, debating underdeveloped issues and future directions.

In these debates, the theorization of agency has emerged as one of the most problematized matters. Castree's (2007:858) argument that "agency is both under-theorized and under-specified in most labor geographers' analyses of it" continues to be relevant. Although there seems to be a consensus among labor geographers on this matter, the debate also involves apparent differences of opinion. Tufts and Savage (2009), for example, assert that the agency of labor is not as important in constructing theoretical and analytical boundaries as it is in defining labor geography as a political project. Coe and Jordhus-Lier (2011), on the other hand, argue that the issue of theorization of labor's agency is also an analytical problem, given the massiveness and complexity of the material and immaterial realms encircling labor. According to Das (2012), not only the notion of labor's agency but also labor geography's view of class is problematic and inadequate to grasp the spatiality, relational totality and multidimensionality of class struggle.

Nevertheless, the problem of under-theorized agency has still been generating limits for the further development of labor geography. This is mainly due to the fact that the issue of under-theorized agency is also linked to the issue of under-theorized structure. In other words, the labor geography project remains under-developed in terms of "how and why workers and 
capitalists act the way they do" (Herod, 2012: 349). In this regard, Coe and Jordhus-Lier (2011) argue that labor geography needs an analytical framework - if not a complete theory - to explore the socio-spatial dynamics that cause variations in workers' actions. They suggest a constrained and variegated notion of labor agency, arguing that space and social relations are fundamental to understanding agency's praxis of geography-making, due to the fact that both the conditions and the strategies of agency are spatial. In this regard, they examine the notion of agency in relation to four main socio-spatial constraints: capital, the state, the community and labor market.

Although Coe and Jordhus-Lier's (2011) argument can be seen as important progress in relation to the theorization of the dialectic between agency and structure, this account nevertheless falls short by not addressing the role and embeddedness of uneven geographical development in the production and configuration of geographical spaces, socio-spatially differentiated inter-class relations and the agency and praxis of grassroots movements. With our paper we aim to take Coe and Jordhus-Lier's (2011) contribution further by arguing that grassroots agency should always be seen in relation to not only capital, state, community and labor markets, but also unevenly developed geographical space in which the class forces, relations, struggles and praxis are variably embedded.

In this respect, we argue that rather than identifying individual structural constraints or categories, an expanded notion of socio-spatial structure can be adopted into the scrutiny as a modularized image of the whole that allows us to explore the agency's praxis with respect to uneven geographical development. In a broad sense, by the concept of socio-spatial structure, we refer to a relatively coherent configuration of socio-spatial relations that defines and differentiates inter-class relations in an unevenly developed geographical context. Here, we address Harvey's (2006b:102) argument of 'production of regionality'. For Harvey, capitalism's uneven geographical development perpetually produces 'regional spaces', where "production, distribution, exchange and consumption, supply and demand, class struggle, culture and lifestyles hang together within an open system that nevertheless exhibits some kind of "structured coherence"”. According to Harvey, such regional structures can evolve into territorial units that operate as defined spaces of agency's collective action. In this respect, we argue that an analytical focus on preeminent axes of such socio-spatial structures can serve labor geography as a considerable contextual leverage to explore the constrained nature of agency with respect to uneven geographical development. 
Now, we must turn our critical attention to a different but related debate within labor geography. Since its emergence in the late 1990s, the labor geography literature has been characterized by a long-standing debate over its traditional worker/union-centrism in relation to agency (Das, 2012; Coe and Jordhus-Lier, 2011; Castree, 2007). A historical look at labor geography enables the identification of an evolving strand of contributions attempting to overcome this centrism through community-unionism. Preliminary studies within this strand have mainly addressed cases showing how labor unions improve their organizational and struggling capacities through adopting community-unionism practices whilst dealing with emerging threats of industrial regulations and restructurings (Tufts, 1998; Johns and Vural, 2000; Walsh, 2000; Ellem, 2003). These contributions have paved the way for the second wave of contributions, which is identified by an increasing interest in theorizing and framing community-unionism in relation to spatiality of labor as well as national and international scales of coalition-building in global production networks (Lier, 2007; Ellem; 2008; Wills, 2008; Oseland et al., 2012; McDonald et al., 2012; Jordhus-Lier, 2013; Brookes, 2013).

Overall, this evolving and strengthening strand suggests an important shift from the dominant worker/union-centrism to a more flexible and broader understanding of labor's agency in relation to the wider community. However, despite these progressive contributions, this strand is still greatly under the influence of the dominant perspective in several respects. To begin with, whilst linking labor to the wider community, this strand still tends to confine the class-struggle and labor's agency to unions, and thereby, pre-requires and prioritizes empirical cases with workplace/industry-based confrontations to explore class agency. Besides, this strand still conceives of other social classes and strata outside of the proletariat simply as 'reinforcements' on which to capitalize, ignoring grassroots' collective and interdependent potential of shaping the geography of capitalism and bringing about fixes from below. Furthermore, a vast majority of cases explored in this strand are from developed country contexts. Thus, we reiterate Tufts and Savage's (2009) argument that labor geography needs a new perspective for cases in different spatial contexts, i.e. in the Global South, where the exercise of 'agency' takes on different form and meaning.

We argue that this strand's contributions need to be complemented by a grassroots agency perspective in order to go beyond the worker/union-centric narrowness of previous labor geography. We define grassroots agency as a collective form of socio-spatially constrained class-struggle acting towards the materialization of commonized inter-class 
interests. Our conceptualization of grassroots agency differs significantly from both worker/union-centrism and reciprocal forms of unionism. In our perspective, the notion of labor's agency is not confined to a privileged minority of unionized workers. Rather, our perspective allows us to comprehend collective agency of labor and its class allies with their realities constrained by various axes of socio-spatial structure such as ethnicity, race, gender, religion, culture, history, ecology, politics, economy, and so on. Analogous to our argument here, but originating from the Marxist-Feminist literature, Ferguson (2016), while discussing the limitations of intersectionality feminism and suggesting an integrative ontology for socialreproduction feminism, underlines that labor and its collective agency must be seen as a complex, diverse unity both within and beyond the capitalist social totality. By taking inspiration from this account as well as Das' (2012) call for an alternative view of class and agency, we argue that such a more comprehensive and dialectical ontology of the social can assist the pluralist school of labor geography in two respects. On the one hand, it enables us to grasp how the capitalist socio-economic formation is produced and reproduced by collective, interdependent and practical human activity taking place within organized and unevenly developed capitalist spaces. And, on the other, without de-emphasizing the agency of labor but integrating it into a broader, multi-dimensional and relational conception of class, the premised ontological perspective provides a dynamic and complex understanding of class unity and struggle, which traditional labor geography often fails to address. In other words, the perspective we are proposing turns analytical attention from the existing versions of the unionworker centrism to the realm of grassroots agency, in which laboring classes and their class allies participate with variegated and interpenetrating economic, political and ideological agendas and organizations.

Lastly, our paper problematizes traditional labor geography's unilateral approach to the issue of spatial displacement of crisis. In the labor geography literature, the concept of labor's spatial fix has been developed as an alternative metaphor to capital-centric rendering of the spatial fix (Peck, 2003) in an attempt to understand how workers overcome the problems of their self-reproduction and survival whilst shaping economic landscapes through their praxis. Here, Coe and Jordhus-Lier's (2011) and Das' (2012) critiques of traditional labor geography's bias towards isolated success stories of workers are welcome interventions, allowing us to recognize the ongoing bias as an inevitable corollary of the unilateral and non-dialectical distinction made between labor's and capital's spatial fixes. We argue that making such a clearcut distinction between capital's and labor's spatial fixes and setting one against the other is 
not dialectical enough. Paraphrasing Engels' words (1892/2008: 47), both capital's and labor's fixes are as inseparable as they are opposed and that despite all their opposition, they mutually interpenetrate. A similar argument to our critique of the labor geography's unilateral understanding of spatial displacement of crisis has been put forth by Campling et al. (2016) in relation to development literature, arguing that capitalism is constituted through and by class struggles at and beyond the point of production, and therefore struggles both from above and below must be seen as constitutive elements of the historical expansion, intensification and transformation of capitalism. Furthermore, through employing a class-relational approach, this account also brings an important insight into the constraining or facilitating role of a variety of socio-spatial axes of social difference such as ethnicity, race, caste, location, sector, gender, and so on, in shaping the agency of capitalist and laboring classes toward a collaborative or antagonistic praxis.

Thus, through our paper, we turn our focus to the potential coalescences between capital's and labor's needs, interests and their conjoined praxis of making geographies and displacement of crisis, which remains considerably under-researched in the labor geography literature. Here, we borrow Herod's (2003) and Harvey's (2006b) interpretations of regional 'growth machine politics' in order to explore the dialectic nature of capital's and labor's praxis towards displacement of crisis. Harvey (2006b: 103), in his theory of uneven development, addresses a typical form of regional class alliances and struggles, which seeks to establish a pattern of governance in which the stakes are fundamentally the economic health and wellbeing of the region rather than class. According to Harvey, such regional struggles and class alliances are characterized by "regional growth coalitions" to improve the competitive strength of the territory vis-à-vis other territories, and in such forms of struggle, the local bourgeoisie may support territorial struggles and join a local class alliance on the grounds of improving the welfare of the region. Analogous to Harvey (2006b), Herod (2003) also points out that workers participate in what he calls local boosterist campaigns to defend or improve their economic spaces because they have no other choice.

To explore the inter-class politics of development in the form of regional growth coalitions, we adopt Wright's (2000) notion of positive class compromise. Wright, while exploring the relationship between the associational power of workers - the various forms of power that result from the formation of collective organizations of workers - and the interests of capitalists, points out a 'positive' form of 'class compromise' that allows both opposing 
classes to improve their position through active and mutual cooperation. According to Wright, the laboring class' associational power has two distinctive effects on capital's interests. On the one hand, it put the brakes on the capitalists' capacity to make unilateral decisions, and on the other, it is potentially beneficial to capitalists' interests by helping the bourgeoisie solve its collective action and coordination problems. Important empirical evidence for Wright's argument on positive class compromise is provided by Selwyn's (2011) overarching work examining the evolution of labor's militant struggles towards a class compromise in the Brazilian horticultural export sector. Through his case study, Selwyn clearly demonstrates that leading employers in São Francisco's fruticulture sector have capitalized on workers' associational power to solve their collective action problems.

Building on these critical accounts, we propound a concept of socio-spatial fix to explain how the grassroots' praxis of geography-making and crisis-resolution conjoin with and assist capital both in staving off its recurrent crises embedded in socio-spatial structures and in recovering itself via the reproduction of new capitalist spaces and capitalist social relations. In this regard, we argue that socio-spatial fixes from below have a dialectical nature. On the one hand, it is a bottom-up response to existing crises embedded in a socio-spatial structure and therefore mainly seeks to maintain and reform the reproductive potential and livelihoods of the grassroots. On the other hand, such a grassroots socio-spatial fix aids capital's spatial displacement of crisis, enabling it to reproduce its own logic of accumulation and circulation.

\section{Methodology}

In our research, we adopted a qualitative approach to explore the case of the hydroelectric power plant projects and struggles in Dêrsim, Turkey. The data were obtained in three phases by using multiple methods: observations, in-depth interviews and secondary data sources.

Observations. The observational data were gathered from one of the researchers' personal experiences in Dêrsim within different periods of time between 2000 and 2016. During this time, the researcher attended a wide range of events varying from festivals to protests, took field notes and photographs, and communicated with locals and activists. The participant researcher repeatedly and iteratively discussed the observational data with the outside researcher to eliminate emergent subjectivities. The observational data guided the 
researchers in identifying Dêrsim's socio-spatialities, key confrontations and characteristics of the struggle and emerging changes in socioeconomic and sociocultural discourses and practices in Dêrsim.

Interviews. Following the observation phase, a semi-structured interview draft was formed and 29 in-depth interviews were conducted. In the selection process of interviewees, a snowball sampling method was preferred to access the most knowledgeable agents in the field. Interviewees consisted of committee members and representatives of activist groups, labor unions, occupational and local associations, communities, journalists and an academic from the local university. Overall, the interviewees held a positive stance towards Dêrsim's anti-dam struggle. However, there were significant disagreements among interviewees about certain issues such as the power struggle between activist groups, accumulation practices by the locals and political partiality in the organization of activities related to the struggle. Through conversational dialogues rather than directive questioning, the interviewees were encouraged to generate the logical reasoning behind the key characteristics of the struggle and emerging changes in socioeconomic and sociocultural discourses and practices in Dêrsim. This interview data were also added to the existing observational data and the new dataset was completely reanalyzed to examine the status quo in Dêrsim. Throughout this paper, to ensure confidentiality, the interviewees' identities and occupations will not be revealed.

Secondary data sources. Based on the data gathered in the previous two phases, we also conducted a web-based data search, and gathered data from multiple web-sources including official reports, statistics, columns in local newspapers, personal blogs and social media websites. This secondary dataset was also added to the existing data and used to improve the quality of analysis. The majority of the secondary data gathered is cited both in-text and in the references. However, to protect the identities of certain secondary data sources such as newspaper columns, personal blogs and social media websites, authors' names were not disclosed.

A systematic analysis process was applied for the examination of the data. Firstly, the data derived from observations were categorized under three main themes: 'emerging-existing confrontations in Dêrsim', 'characteristics of the grassroots struggle' and 'emerging-existing socio-spatial configurations'. Then, the interviews containing interviewees' responses and reasonings concerning the three identified themes were fed verbatim into the analysis, and the new dataset was re-examined for identical comments. Lastly, the secondary data were also 
included in the analysis process to improve our analysis of the case. Finally, the data collected in all three phases were refined, re-developed and re-analyzed in an iterative and interactive manner.

\section{The case of Dêrsim's anti-dam struggle}

\section{A contextual background of the dam projects in Dêrsim}

Uneven geographical development lies at the heart of the entire capitalist economy. In seeking areas of investment, certain geographies appear as cost-effective spaces, providing more profitable investment opportunities for capital. In the geographical restructuration of capital, the construction projects of dams in Dêrsim have emerged with the target of putting the province's rich water resource potential at capital's disposal. In line with this target, many preeminent capital actors of the Turkish oligarchy such as Boydak, Limak, Soyak, Ata, Zorlu, Saran, Aksa, Bilgin, Ağaoğlu holdings as well as leading foreign energy and mining corporations from the USA, Austria, UK and Australia, such as Stone \& Webster, Strabag, VA Tech Voest, VA Tech Elin, VA Tech Hydro and Rio Tinto, have turned their attention to Dêrsim's natural riches. According to data derived from various official sources (Governorship of Tunceli, 2016a, 2015b; Ministry of Forestry and Water Affairs 2012; Ministry of Environment and Forestry, 2009; Ministry of Justice, 2013; DSİ, 2009), in total, there are 92 projects on Dêrsim's water potential. Of these 92 projects, 30 focus on the construction of hydroelectric dams and regulators, of which 8 have been completed and are currently in operation with an installed energy capacity of 433.35MW (EPDK, 2017). On the completion of the remaining 22 dam projects that are still in progress, the total installed energy capacity of the hydro dams linked to Dêrsim will reach a thousand MW (EPDK, 2017; FKA, 2015). Of the other 62 projects, 10 are projects involving construction of irrigation dams and ponds and the remaining 52 are projects involving the construction of flood protection and stabilization facilities. Moreover, 22 new mining projects and many quarrying projects have recently been planned and approved along with the dam projects (Governorship of Tunceli, 2016a, 2015b). The major construction projects in Dêrsim are illustrated in Figure 1 below.

\section{Figure 1: Major projects in Dêrsim}




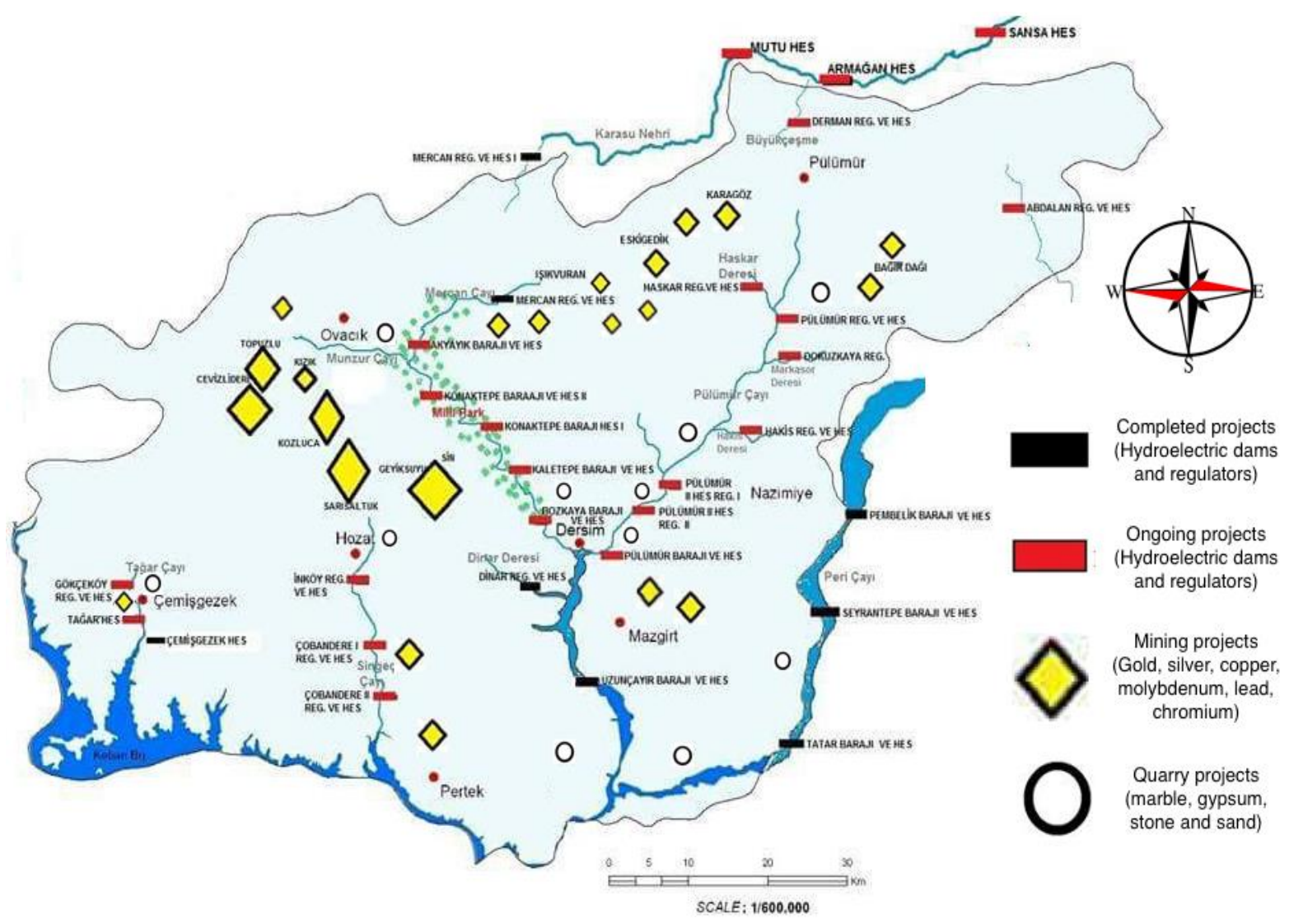

Source: Interviewee A, 2016; Governorship of Tunceli, 2016a, 2015b

As Dissard (2017) argues, the Turkish state and capital are targeting every potential river in Turkey to build dams regardless of the ethnic or religious axes of social difference. Nevertheless, we take his contribution further, arguing that such axes of socio-spatial difference are vital to understand how and why Dêrsimites have acted in the way they have. The following subsection will focus on this matter, exploring how the interplay between the dam projects and Dêrsim's socio-spatial structure has defined the main confrontations on which Dêrsimites' anti-dam struggle is built.

\section{Dêrsim's socio-spatialities and the confrontations associated with the dam projects}

Dêrsim, as the least populated province of Turkey with a population of 82,193 (Turkstat, 2016a), has been suffering from a lack of socioeconomic growth as the corollary of uneven geographical development. The province is one of the least economically developed in Turkey (Ministry of Development, 2013). Agriculture, sheep and goat farming, cattle farming, beekeeping, dairy production and fishing are the main dynamics of Dêrsim's economy. 
Production processes rely heavily on traditional methods using traditional equipment and machinery (Turkstat, 2014). The level of industrial development in Dêrsim is noticeably limited, given that there are only four manufacturing industry companies employing 10 or more workers (Provincial Directorate of Environment and Urbanization, 2017). Thus, the local economy is mainly built on small-scale economic activities relying heavily on small peasantry, petty bourgeoisie and a relatively limited number of laboring class members employed by the province's underdeveloped bourgeoisie operating in the small-sized service and industry sectors.

Moreover, Dêrsim has also been experiencing sociocultural growth problems as a result of the systematic assimilation policies pursued by the Turkish state. This is mainly due to a relatively distinctive socio-spatiality. Dêrsim stands out from all other provinces in Turkey by virtue of its majority population of Alevi Kurds. As Dissard (2017) clearly underlines, this distinctive mix of ethnic origin and religious belief differentiates Dêrsim from both Turkish and Kurdish majority provinces in Turkey, making the province the only one where the Alevi Kurd minority holds the majority position. However, the Turkification and Sunnification policies that have been performed since the Ottoman period have been strangling the sociocultural development of Dêrsim. These policies are still prevalent in the Turkish Republic to this day (Ronayne, 2005). In line with these policies, the Turkish state changed Dêrsim's name to Tunceli in 1935 and over the course of time, officially banned the use of the Alevi Kurds' language, folklore, rituals, ceremonies, names and even the word 'Kurd' (Official Gazette of the Republic of Turkey, 1935; Beşikçi, 1990).

As a consequence of the chronic socioeconomic under-development and historical assimilation policies targeted at Alevi Kurds, the province has been characterized by a deeprooted struggle-tradition since Ottoman times (van Bruinessen, 2000; Çem, 2009). Over the course of time, Dêrsimites' historical uprisings, which had initially been led by local Kurdish Alevi chieftains, have evolved into an integral part of labor's armed political parties since the mid-1970s. In this respect, chiefly TKP/ML (The Communist Party of Turkey/MarxistLeninist), MKP (The Maoist Communist Party), PKK (The Kurdistan Worker's Party) and DHKP-C (The Revolutionary People's Liberation Party-Front) have become the key influential actors in Dêrsim's political, ideological and democratic spheres of governance as a corollary of their wide-ranging public support.

The dam projects in Dêrsim were erected over such socio-spatially differentiated 
geography. In this context, the key confrontations in this case have emerged in accordance with the socio-spatialities of Dêrsim. One of the main confrontations frequently emphasized during the interviews is the (e)migration of Alevi Kurds away from the region, which has been further accelerated by these projects. As a consequence of the socioeconomic backwardness of the province and the systematic oppression of Alevi Kurds, Dêrsimites have been continually moving either abroad or to more developed provinces in Turkey. The official statistics show that a total of 139,196 people (e)migrated from Dêrsim between 1980 and 2015, which is over 1.7 times the province's current population (Turkstat, 2016b). According to a parallel report submitted to UN (CounterCurrent, 2011), the Uzunçayır reservoir, one of the completed dam projects in Dêrsim, flooded several villages. The report also states that if all of the planned dams are constructed, 84 of the 365 villages in Dêrsim (Turkstat, 2014) will be displaced and the inhabitants subject to loss of their houses, fields and pasture for their livestock in the reservoirs.

The footprint of this threat posed by the dam projects is significantly larger than expected when their cumulative impacts are taken into account. McCully (2001) underlines that the globally increasing capital investments in dams have resulted in poor economic return, but massive environmental and social destruction for so-called 'developing' economies. Similarly, the World Commission's report (2000), considering the magnitude of impacts of dams, states that 40-80 million people were displaced globally and $60 \%$ of the world's rivers have been negatively affected by dams. In this regard, the dam projects inevitably have a cumulative impact on the wider socio-spatial relations such as agricultural production, livestock and fishing processes; these being the main economic activities in Dêrsim. It is likely to cause changes in a great number of socio-spatialities such as water quality, irrigation and farming methods, soil structure, cultivable crops, pasture areas and pathways for the livestock, fish fauna, biodiversity losses, climatic systems, and so on (Ronayne, 2005). Moreover, with the completion of the ongoing projects, the physical connections between provincial capital and districts will be hindered due to the flooding of some of the main roads, further accelerating the (e)migration of people. In 2015, we observed a paradigmatic example in the Qisle district of Dêrsim. Two people from the Arduç family, who live in Yeresk village, went on hunger strike to protest against the village's loss of access to Qisle district for over a year, as a result of the completed Pembelik dam project that submerged the roads and bridges connecting the village to the rest of the district. The family's struggle resulted in the promise of a bridge made by capital and state actors (Governorship of Tunceli, 2015a). Many interviewees asserted that 
there was also a political and military agenda behind this physical disconnection caused by dam projects, so as to prevent the people of Dêrsim supporting the guerrilla warfare of labor's armed-political parties, through isolating guerrillas from locals and incarcerating the guerrilla war in certain rural fields. In response to this militarist agenda, the dams in Mercan and Dinar have been the subject of bombing attacks by the TKP/ML (Dissard, 2017).

Another confrontation repeatedly stressed during interviews is the projects' potentially devastating effects on Dêrsim's ecological socio-spatialities. Dêrsim's flora and fauna consist of 1,806 taxa of animals and plants, of which 261 are endemic. Of these 1,806 observed taxa, 2 are in the IUCN extinct category, 12 are in the critically endangered category, 22 are in the endangered category, 38 are in the vulnerable category and 65 are in the near threatened category (Ministry of Forestry and Water Affairs, 2016). The dam projects pose a threat to the main sources of such rich biodiversity, bringing Dêrsim to the brink of losing almost all its main water sources giving life to the province's flora and fauna. Moreover, Dêrsim's key natural parks and valleys (Munzur, Peri, Pilêmorî, Mercan, Tağar and Hağaçur valleys), as the main natural habitats of animals and plants living in the province, are also under threat of being submerged in water or being impacted at significant levels (Ronayne, 2005).

This ecological confrontation is linked to another socio-spatiality of Dêrsim. In the Alevi Kurds' faith, nature means more than simple physical materiality. Dêrsimites believe in the sanctity of nature, and attribute a metaphysical immateriality to certain mountains, waters and rivers, animals and plants (Çem, 2009). The location of such natural beings is known as 'ziyaret', which Dêrsimites frequently visit to express their gratitude to their wise ancestors, murshids, rehbers, pirs and dervishes. In addition to their spiritual functions, ziyarets are also identity, solidarity and cooperation centers that bring Dêrsimites together under shared sociocultural commonalities. The dam projects have caused submersion of many ziyarets as well as a great number of historic-cultural socio-spatialities including monasteries, churches, bridges and temples from medieval times (Dissard, 2017; Ronayne, 2005).

\section{Compositional pattern and alliance formation of Dêrsim's anti-dam struggle}

In conformity with Dêrsim's socio-spatialities and the main confrontations arising from the dam projects, the anti-dam struggle in Dêrsim has gone beyond the typical ecological mobilization against dams, incorporating other ethnic, religious and economic confrontations 
historically embedded in Dêrsim's socio-spatial structure. Therefore, through their struggle, Dêrsimites have not only aimed to stop the dam projects by means of an ecological movement, they have also targeted Turkey's suppression of Dêrsim's Alevi Kurds, as well as the chronic underdevelopment of the province that characterizes the survival and self-reproduction problems of all classes in Dêrsim.

Here, we dissent from Dissard's (2017) interpretation of Dêrsimites' anti-dam struggle. According to Dissard, the anti-dam struggle represents a shift from 'Red' to 'Green' political activism, in such a way that the traditional Leftist discourses and practices against capitalism, imperialism and the state have been replaced by the preservation of the environment against the same foes. However, our interpretation of the case is different. We argue that this 'green' dimension represents a deepening of class struggle that not only forces all sorts of classes in Dêrsim to attune their class interests to the changing and emerging socio-spatial relations, but also provides a political ground for class alliances vis-à-vis their historically ongoing problems of survival and self-reproduction. Thus, a closer look at the anti-dam struggle reveals that its compositional pattern is a mixture of economics, minority rights and ecological movements, politically and ideologically linked to labor's armed political parties.

As we addressed previously, the noticeable influence of labor's armed political parties in Dêrsim is not new, but a historically produced socio-spatial relation embedded in Dêrsim shedding light on today's anti-dam struggle. This influence became apparent when the armed conflict between the Turkish state and the PKK gave birth to a peace process in the 2000s. The peace process provided a relatively democratic atmosphere in terms of freedom of speech, expression, association and participation in local governance. Thus, labor's armed political parties increasingly leaned towards entering local and general elections and organizing all Dêrsim's classes in democratic spheres of governance. Along the lines of this new political direction, candidates and organizations associated with labor's armed political parties successively increased their votes in local and general elections as well as their legitimate power in local municipal governments, particularly during the peace process (The Supreme Electoral Council, 2017).

In Dêrsim, a great majority of ecological, democratic and minority rights organizations that have brought the anti-dam struggle into existence are widely known for their political and ideological affiliations to one or another political party of labor. As a result, the leading organizations of the anti-dam struggle have been frequently targeted by the Turkish state under 
suspicion of being controlled and directed by the armed political parties of labor. For example, an interviewee from DHF (Demokratik Haklar Federasyonu - Democratic Rights Federation), one of the leading grassroots organizations behind the anti-dam struggle, noted that their organizations were raided by the police in 2010 and five of their comrades who had been organizing the anti-dam struggle were sentenced to a total of 125 years' imprisonment due to the accusation of being linked to MKP (Interviewee B, 2016). Similarly, following the collapse of the peace process, a number of our interviewees, many leading actors behind the anti-dam struggle such as elected provincial and district municipality mayors and authorities, activists of Dêrsim's grassroots organizations, labor unions and environmentalist groups, were either detained, jailed or dismissed. A number of Dêrsimites' democratic institutions were also closed down and local municipalities transferred to the appointed trustees by the Turkish state (Official Gazette of the Republic of Turkey, 2017; Ministry of Interior, 2016; Governorship of Tunceli, 2016b).

However, through organizing the anti-dam struggle with this multiple compositional pattern, labor's influential parties in Dêrsim have enabled the banding of all classes under a class coalition against the Turkish state and capital actors' historical and actual policies and practices targeted at Dêrsimites. In this respect, the alliance formation of Dêrsim's anti-dam struggle emerged as a coalition of the oppressed classes and strata of Alevi Kurds and Dêrsim's underdeveloped local bourgeoisie, which served as an inter-class platform for the agency and praxis of grassroots movements and their geography-making and crisis resolution.

A number of dynamics historically embedded in Dêrsim's socio-spatial structure have enabled the emergence of the said class coalition. Firstly, by bringing about new confrontations such as deprivations of nature-dependent production cycles, displacement of Alevi Kurds and their livelihoods, acceleration of (e)migration waves, radical changes to the cultural, economic and social makeup of landscapes, and so on, the dam projects have emerged as an increasing threat not only for laboring classes, but also for Dêrsim's underdeveloped local bourgeoisie in terms of their common problems of self-reproduction and survival. Thus, in response to the broadening scope of the threat, Dêrsim's local bourgeoisie, for the first time in history, became organized and took part in the struggle chiefly led by grassroots organizations linked to labor politics. They frequently and explicitly stressed the negative outcomes of the dam projects for the local economy (TÜRKONFED, 2014), and manifested their negative stances against the Turkish state's policies targeting Dêrsim's ethnic, religious and cultural values as well as their 
financial support for the grassroots (Tunceli Chamber of Commerce and Industry, 2017; Tunceli Industrialists and Entrepreneurs Association, 2017).

Furthermore, ethnicity and religion, as two main distinctive axes of the socio-spatial relations in Dêrsim, have also laid the foundations for this class coalition. Representatives of DHF and DEDEF (Dersim Dernekleri Fedarasyonu - Federation of Dersim Associations), proMKP and pro-TKP/ML organizations leading the struggle, described the dam projects as the Turkish state's new mode of the historical and systematic oppression of Dêrsim's Alevi Kurds. In line with their interpretation, they identified Dêrsim's struggle not only as a reaction against the dam projects, but also a defense against the Turkish state's never-ending attacks on the laboring classes of Dêrsim (Interviewees C and D, 2016). The following comment should be noted:

"The dam constructions in Dêrsim are another step in the never-ending ethnic cleansing project by the Turkish state. (...) Dêrsim has been subjected to many ethnic cleansing attempts, including genocides, massacres and exiles since the days of the Ottoman Empire. In the period of the Turkish Republic, we again experienced the Dêrsim Massacre in 1938. Again, in the 1990s, Dêrsimites were made to leave their lands through forced evacuations, burning down of villages and numerous 'unidentified' murders. The scope of the threat was our lives in 1938; then it was enlarged in 1990s by targeting our lives in our common living spaces; and today, it is aimed at our lives in our common living spaces as well as our nature” (Interviewee D, 2016).

Lastly, the relatively democratic atmosphere provided by the peace process between the Turkish state and the PKK had also enabled the emergence of this class coalition. The number of associations established by Dêrsimites has almost doubled from 67 to 132 (Ministry of Interior, 2017) in the most shining period of the peace process, when for the first time Turkish Prime Minister Erdoğan used the term "Kurdish question" in his Amed speech in 2005, and when the Turkish state killed 34 unarmed Kurdish civilians in the 2011 Roboski Massacre (Grand National Assembly of Turkey, 2013). Similarly, for the first time in Dêrsim's history, candidates nominated by labor's political parties were elected to parliament in the 2007 and 2015 general elections and came to power in provincial and a number of district municipalities successively in the 2009 and 2014 local elections (The Supreme Electoral Council, 2017). 
Under such a compositional pattern and alliance formation, the preliminary foundations of Dêrsim's struggle were laid in 1998 by the 'Spend your holiday in Dêrsim' campaign to encourage remigration and to bring Dêrsimites together against the approaching threat of the dam projects. The campaign idea evolved into the 'Munzur Culture and Nature Festival' in 1999. However, the Governorship of Tunceli banned the festival. In 2000, the struggle broke the governorship's ban policy on the festival. After 2000, despite the ban policy, Dêrsimites have continued to organize the festival. To put the brakes on Turkey's suppression of Alevi Kurds' sociocultural identity, Dêrsimites revived their language, folklore, rituals and histories, particularly during the festival periods. Eventually, the festival became one of the most popular in the country and achieved its main goals. When official statistics (Turkstat, 2016b) are taken into account, Dêrsim's (e)migration rates have gradually declined since the early 2000s. Particularly after 2008, for the first time in Dêrsim's history, the province began to receive more inward than outward migration. Dêrsim has also become an attraction for dissidents from other geographies of Turkey and consequently, Dêrsim's seasonal population has increased considerably during the festival periods. Moreover, the festival has significantly broken the bans on Alevi Kurds' identity and increased the social awareness of the local people. In 2010, Dêrsim held an anti-dam protest march with over 20,000 protestors; the highest level of participation ever recorded in an environmental protest in Turkey (CounterCurrent, 2011).

\section{Reproduction of capitalist social relations and spaces in Dêrsim}

In parallel with the successive festivals, the economic dimension of the struggle has become more apparent and given birth to new socio-spatial relations, triggering the production of the capitalist social relations and capitalist spaces. Along the lines of the established class coalition, between 2000 and 2016, we observed that the grassroots organizations initiated a local boosterist campaign - to use Herod's (2003) expression - allowing the local people to integrate in capital accumulation through the commodification of Dêrsim's nature, culturalhistorical customs and political histories.

One of the paradigmatic examples of the struggle-originating capital accumulation practices is Munzur A.Ş., which is a joint-stock bottled water factory that commenced production in 2005, with an initial capital investment from 240 local inhabitants. The company, which is now the sole exporting company in Dêrsim, employs over 40 locals and distributes 
six types of bottled water product, not only throughout Turkey but also to Germany and Iraq via its 42 national and international authorized dealers. Munzur A.Ş. was established in line with the local boosterist campaign as a local bottom-up development project. A representative from DEDEF, as one of the leading actors behind the Munzur A.Ş. project, clarified the social rationale for this project: "to solve the economic and sociological problems in Dêrsim through sharing $10 \%$ of the company profits in order to set up new local businesses that can contribute to Dêrsim's development" (Interviewee E, 2016). As a marketing strategy, the company also widely capitalized on material and immaterial sociocultural patterns identifying with Dêrsimites' ethnic, religious and cultural socio-spatialities. However, in favor of the 'social' rationale, Dêrsimites have condoned the commodification of their sociocultural artifacts as well as the Munzur river, which is a paramount 'ziyaret' in the Alevi Kurd faith.

"Munzur A.Ş. can be considered as one of the serious mistakes of the anti-dam movement because it commercialized nature (...) Indeed, Munzur A.S. deviated from its social purposes and transformed into a typical capitalist enterprise over the course of time." (Interviewee F, 2016)

The Munzur A.Ş. experience played a frontier role in the legitimization of nature's commodification in Dêrsim. Paradoxically, in accordance with the legitimate grounds provided by Munzur A.Ş., the dam project in Dinar was completed by Elda-HGG Construction Inc., which is a local company having publicly known connections with the grassroots organizations. Furthermore, the trend of accumulation through commodification of nature has also stimulated the service sector, particularly tourism. Dêrsim's mountains, lands, paths, rivers, riverbanks and underground waters were also transformed into spaces for capital accumulation, such as places of entertainment, beaches, picnic and camping sites, thermal spa facilities, restaurants, and so on.

The subjects of commodification are not limited to Dêrsim's nature. The historiccultural and sociopolitical values have also been transformed into commodities by the locals in accordance with the local boosterist campaign. The following comment exemplifies the main commodification processes that we observed in Dêrsim:

"One month before and after the festival period you can find a wide array of products on the market stalls. The municipality [pro-PKK] rents the market places for the sake of the local economy's development. The stallholders sell products containing 
political, historical, cultural and religious symbols or figures that have an important place in Dêrsim people's lives. (...) People have no idea what they are buying or selling! They actually exchange our beliefs, values, culture, history and even religion in the form of commodities. We weren't used to this kind of exchange relations until 1015 years ago." (Interviewee G, 2016)

Overall, there has been an atmosphere of tolerance for the accumulation practices performed by Dêrsimites. A great majority of people we interviewed explicitly stated that these economic activities were "the only beneficial result of the dam projects" (Interviewee H, 2016). The established consensus on regional growth politics is also extensively reflected in the interviewees' comments. The locals explained their tolerance of the accumulation through appropriation of Dêrsim's nature, culture and histories by putting forward the argument of their economic wellbeing. The following comment can be noted: "The capitalist system is established on the commodity and therefore we should connive the commercialization in Dêrsim. Why should it only be other people in Turkey who make money? Let Dêrsimites make some money!" (Interviewee I, 2016). A labor union representative clearly explains their positive stances toward the commodification practices in Dêrsim as follows:

"The main contradiction of the labor movement up until now in Turkey is the understanding of labor movement merely as a field of opposition. The majority of labor organizations in Dêrsim think that such understanding doesn't improve, but marginalizes our struggle. (...) If you tell people that they must be against commodification, they will reply that they are starving, they are landless, they have no alternative except moving away. By doing so, you lose public trust, and when you lose public trust, people come closer to the capitalist system. To avoid this, labor organizations in Dêrsim have been adopting a new perspective, offering alternative methods of development and creating new job opportunities and work areas. Thus, we see these commodification practices as a corollary of having no alternative ways of living, and support these economic activities unless they harm the environment" (Interviewee J, 2016).

\section{Discussion}

Socio-spatially constrained agency 
The Dêrsim case provides an empirical example showing the capacity of socio-spatial structure to constrain grassroots' collective action. In Dêrsim, the socio-spatial structure has acted as a structural constraint shaping grassroots agency in a variety of ways. First, the emerging confrontations associated with the dam projects, which brought about grassroots agency in Dêrsim, have strongly connected with the socio-spatial characteristics of the province. These confrontations include the displacement of Alevi Kurds, deprivations of agricultural production, livestock and fishing processes, acceleration of emigration and migration waves, destruction of ecological habitats, annihilation of Alevi Kurds' identity, solidarity and cooperation centers, and so on. Our analysis has uncovered that, whilst organizing their struggle, Dêrsimites frequently and repeatedly link these emerging confrontations to ethnic, religious, cultural, historical, political, ecological and economic components of Dêrsim's socio-spatial structure.

Second, Dêrsim's socio-spatial structure also plays a constraining role in framing the compositional pattern of grassroots agency, which, in this case, has gone beyond a typical mobilization against dam projects, evolving into a mixture of economic, minority rights and ecological movements. This is mainly due to the fact that these dam projects are closely connected to other deep-rooted problems embedded in Dêrsim's socio-spatial structure. For example, the problem of the destruction of ecological habitats also implies the undermining of Alevi Kurds' identity, solidarity and cooperation centers as well as deprivations of naturedependent production cycles, which negatively affect the chronic socioeconomic problems of the province.

Lastly, our case analysis reveals that the formation of class alliances between grassroots movements is also constrained by the province's socio-spatial structure. In response to the broadening scope of threat posed by dam projects, the class alliance of the anti-dam struggle has emerged between the laboring classes of Alevi Kurds and Dêrsim's underdeveloped local bourgeoisie. In conformity with this class alliance formation, the anti-dam struggle has given birth to a local boosterist campaign with the aim not only of resisting the dam projects, which would worsen the province's chronic socioeconomic backwardness, but also reviving and developing the province's ethnic, cultural, historical, political, economic and ecological relations.

All these findings discussed above indicate that an analytical focus on socio-spatial structures can provide a considerable contextual leverage to understand the agency's spatiality 
and constrained praxis in relation to unevenly developed geographical configurations. Here, our empirical analysis brings a new insight into the growing debate on the theorization of agency (Castree, 2007; Tufts and Savage, 2009; Coe and Jordhus-Lier, 2011; Herod, 2012). Our case study demonstrates that despite the complexity of the material and immaterial realms encircling the agency (Coe and Jordhus-Lier, 2011), socio-spatial structures can be adopted into scrutiny as modular analytical units not only reflecting the whole, but also significantly advancing our knowledge of the spatiality and constrained nature of agency.

Moreover, by providing an empirical example of how socio-spatially differentiated structural constraints shape agency's praxis, our case study responds to Tufts and Savage's (2009) and Herod's (2012) calls for deeper spatial analysis of cases to explore the variations in agency's praxis and strategies. Here, we also take Dissard's (2017) contribution further. As Dissard (2017: 18) argues, dams are being built on every river in Turkey "unbiased to the fact that these might 'belong' to Turks, Kurds, Sunnis, Alevis, or others”. However, our case analysis of the most longstanding anti-dam struggle in Turkey reveals that the agency and praxis of grassroots movements in Dêrsim is closely linked not only to ethnic and religious, but also political, cultural, historical and economic axes of socio-spatial difference perpetually produced by the Turkish state and capital actors.

\section{Dêrsim's socio-spatial fix}

Thus far, we have discussed how and why Dêrsim's socio-spatial structure acts as a constraint that shapes grassroots agency. Yet, the reverse of this dialectic is also true. That is, grassroots also shape the socio-spatial structure through producing fixes to their problems of self-reproduction and survival. However, different from Herod's (1997) notion of labor's spatial fix, we address the conjoined nature of capital's and grassroots' praxis of geographymaking and displacement of crisis. In this respect, the Dêrsim case has allowed us to develop and adopt a notion of socio-spatial fix to explore how grassroots' praxis towards displacement of crisis conjoins with and assists capital in staving off its recurrent crises embedded in sociospatial structures and the reproduction of spaces and social relations for further accumulation.

The case of Dêrsim can be seen as a socio-spatial fix in a variety of ways. First, our case illustrates that the grassroots struggle has given birth to new socio-spatial relations through reproducing capitalist social relations and capitalist spaces. This has been materialized along 
the lines of the local boosterist campaign, allowing local people to integrate in capital accumulation for the sake of the province's socioeconomic development. In this respect, Dêrsim's socio-spatial fix has conjoined with and assisted capital in facilitating the production of capitalist social relations and spaces, creating a pattern of governance that reproduces and rescales socio-spatial structure under the motto of the economic health and well-being of the province.

Second, it functions as a socio-spatial fix to Dêrsim's socioeconomic and sociocultural growth problems, which have been historically blocked by uneven capitalist development and the Turkish state's assimilation policies. In this regard, Dêrsim's socio-spatial fix also conjoins with and assists capital in strengthening and maintaining the social order through temporally moderating the province's chronic problems, such as perpetually increasing (e)migration, lack of local capital accumulation and capitalist development, permanent social unrest over economic underdevelopment as well as political bans on, and repression of, Dêrsimites' ethnic and religious identities.

Third, by attaching local people and dissident groups to the processes of capital accumulation through commodification, Dêrsim's socio-spatial fix conjoins with and assists capital in providing legitimacy for the capitalist exploitation of nature, culture and histories. Our case analysis has uncovered that the struggle-led accumulation practices have played a frontier role in expanding the wave of appropriation of natural, cultural and historical sociospatialities for the sake of local development and created an atmosphere of tolerance for the accumulation practices performed by the locals. Moreover, the Dêrsim case also shows that such struggle-led accumulation practices, in accordance with the spirit of capitalism, have inevitably resulted in a wave of accumulation through the commodification of Dêrsim's nature, cultural customs and political histories.

The notion of socio-spatial fix we propounded goes beyond 'success stories of workers' dominating the previous labor geography literature (Das, 2012; Coe and Jordhus-Lier, 2011) as well as Herod's (1997) conceptualization of labor's spatial fix. As the case of Dêrsim shows, the socio-spatial fix has a dialectical characteristic. On the one hand, it improves the reproductive potential and livelihoods of the grassroots, and on the other, assists capital's spatial displacement of crisis, enabling it to reproduce its own logic of accumulation. In this respect, the notion of socio-spatial fix that we developed through the case of Dêrsim provides an empirical support to Campling et al.'s (2016) central argument of how capitalism's historical 
expansion, intensification and transformation is mutually constituted through class struggles from above and below.

Furthermore, our analysis reveals that the socio-spatial fix in Dêrsim has been produced by grassroots agency built upon the class compromise between laboring classes and the underdeveloped bourgeoisie of Alevi Kurds. Here, we agree with both Herod's (2003) and Harvey's (2006b) arguments that labor's and other oppressed classes' involvement in such regional growth coalitions is a result of the fact that "they have no other choice". In Harvey's words (2006b: 93), "whole social formations that had suffered mightily from the depredations of capital could conclude that if they could not beat capitalism they may as well join it". However, the local boosterist campaign in the case of Dêrsim can also be interpreted in relation to Wright's (2000) notion of 'positive class compromise', which appears in the form of an active and mutual cooperation between opposing classes to improve their position. According to Wright, this is the case when the laboring class' associational power is strong enough, on the one hand, to block the unilateral materialization of capitalist-class interests, and on the other, to positively contribute to solving the collective action and coordination problems faced by capitalists. In this regard, the class compromise in Dêrsim could be seen as a corollary of the significant associational power of labor's armed political parties having considerable influence in the province's political, ideological, social and democratic spheres.

\section{Towards a pluralist understanding of agency}

Throughout our analysis, we adopted a grassroots agency perspective instead of traditional labor geography's worker/union-centrism. This perspective shift has allowed us to go beyond the previous worker/union-centrism, which fails to fully explain the case of Dêrsim. Our analysis of the case clearly demonstrates that such a collective form of agency cannot be explored entirely by focusing solely on workers' agency, praxis and isolated class interests. Rather, the complexity of realms encircling Dêrsimites' anti-dam struggle necessitates a broader and integrative class agency perspective that enables a grasping of the multidimensional, relational, spatial nature of the reality (Das, 2012) by directing our analytical focus to the mutual cooperation, collective praxis and commonized class interests between labor and its class allies. The grassroots agency perspective has also significantly expanded our understanding of the dynamics that unite Dêrsimites from all sorts of classes. Undoubtedly, the 
first of these is the hydropower projects, which have provoked a massive outcry from all sorts of classes in the province by posing new threats for Dêrsimites. Moreover, however, the ethnicity, religion and political directions of Dêrsimites have also played an important role in compromising inter-class interests. Here, we make an analogy with our findings and Campling et al.'s (2016) argument that the agency of social classes in the process of development is not only shaped by intra- and inter-class relations, but also interwoven with other socio-spatial axes of race, ethnicity, gender, caste, citizenship, and so on. Finally, as we addressed whilst discussing Wright's (2000) notion of positive class compromise, the significant influence and associational power of labor's armed political parties in Dêrsim's political, social, ideological and democratic spheres have also enabled the emergence and development of grassroots agency.

Above all, however, our findings bridge three important gaps within a particular strand of contributions in labor geography, which calls for a more flexible and broader understanding of labor's agency (Tufts, 1998; Johns and Vural, 2000; Walsh, 2000; Ellem, 2003, 2008; Lier, 2007; Castree, 2007; Wills, 2008; Coe and Jordhus-Lier, 2011; Oseland et al., 2012; McDonald et al., 2012; Jordhus-Lier, 2013; Brookes, 2013). First, our paper aids this strand of contributions by providing an empirically substantiated framework to explore the cases in the Global South context, which remains considerably under-developed in the labor geography literature (Tufts and Savage, 2009). Second, our case analysis goes beyond this strengthening strand of contributions, which often conceives of other social classes and strata outside the proletariat as simple reinforcements of labor's agency. By adopting a grassroots agency perspective, our analysis of the Dêrsim case has shown that grassroots struggles, as platforms of inter-class solidarity and action, can act as collective agencies with a capacity to make geographies of capitalism and produce socio-spatial fixes to their shared problems of survival and self-reproduction.

Lastly, as we addressed before, the worker/union-centrism in traditional labor geography still reflects this emerging strand, confining agency to unionized workers and workplace/industry-based confrontations. However, the grassroots agency perspective has allowed us to transcend this tendency by exploring how confrontations without a direct link to the workplace gravitate labor and its class allies towards more collective forms of class struggle. For example, in Dêrsim the confrontations associated with the dam projects have interpenetrated more deep-rooted confrontations to do with chronic underdevelopment, 
perpetually producing survival and self-reproduction problems for all classes in Dêrsim. This corroborates Ferguson's (2016) argument that all social relations of production and oppression are internally related and integral to a more complexly-organized capitalist totality, and therefore, there is no compelling reason to prioritize workplace/industry-based confrontations but, instead, necessitates a broader and more dynamic and integrative understanding of class struggle as a complex and diverse unity that, on the one hand, produces and reproduces the capitalist whole and, on the other, seeks to revolutionize it.

\section{Conclusion}

In this paper, we have provided an in-depth case analysis of how the people of Dêrsim - through their grassroots struggle against hydroelectric power plant projects - have produced a socio-spatial fix that both addresses their province's chronic underdevelopment and assists capital in staving off its recurrent crises and reproducing its logic of accumulation. Our empirical case analysis has substantiated our theoretical arguments in relation to the recent trajectory of labor geography, which we perceive as a transitional stage, forming a new school of thought - what might be called 'pluralist labor geography' (Peck, 2017). In this context, our paper has responded to Peck's call for a pluralist labor geography in three respects:

First, our paper has brought new insights into the debate on the theorization of agency within its spatiality and constrained nature (Herod, 2012; Coe and Jordhus-Lier, 2011; Das, 2012; Tufts and Savage, 2009; Castree, 2007). Revisiting Harvey's (2006b) argument of regional spaces, our paper has developed an expanded notion of socio-spatial structure as a modular analytical unit to explore the dialectic relation between structure and agency in relation to uneven geographical development. Our empirical case has demonstrated that an analytical focus on socio-spatial structures embedded in differentiated space-time contexts of capitalism can significantly advance our knowledge of the spatiality and constrained nature of agency.

Second, instead of the community-unionism version of worker/union-centrism, which is arguably dominating labor geography (Tufts, 1998; Johns and Vural, 2000; Walsh, 2000; Ellem, 2003, 2008; Lier, 2007; Wills, 2008; Oseland et al., 2012; McDonald et al., 2012; Jordhus-Lier, 2013; Brookes, 2013), we have adopted a grassroots agency perspective. This perspective shift has allowed us to premise a more comprehensive and dialectical ontology of 
class (Das, 2012) and social-reproduction (Ferguson, 2016), which comprehends the geography-making and crisis resolution praxis from below with respect to the multi-layered, complex and dynamic nature of class-struggle endeavoring to materialize commonized interclass interests in a socio-spatially defined context. In this respect, our paper has contributed to the emerging pluralist school by going beyond labor geography's tendency to confine class and its agency to unionized workers and mostly focus on workplace/industry-based confrontations in a Global North context.

Third, building on Herod's (2003) and Harvey's (2006b) interpretations of regional 'growth machine politics' as well as Wright's (2000) notion of 'positive class compromise' and Campling et al.'s (2016) argument on class dynamics of development, our paper has developed a concept of socio-spatial fix. Our notion of socio-spatial fix has allowed us to go beyond Herod's concept of labor's spatial fix (Herod, 1997), by shifting the analytical focus to interconnections, interpenetrations and concatenations between capital's and grassroots' agencies. That is, despite all their differences, capital and grassroots movements have a lot in common. The idea of socio-spatial fix shows how the agencies of both capital and the grassroots can conjoin with and assist each other in relation to geography-making and displacement of crisis. 


\section{References}

Bergene AC, Endresen SB and Knutsen HM (2010). Missing Links in Labour Geography. Farnham: Ashgate Publishing.

Beşikçi İ (1990) Tunceli Kanunu (1935) ve Dersim Jenosidi. İstanbul: Belge Yayınları.

Brookes M (2013) Varieties of power in transnational labor alliances: an analysis of workers' structural, institutional, and coalitional power in the global economy. Labor Studies Journal, 38(3), 181-200.

Campling L, Miyamura S, Pattenden J and Selwyn B (2016) Class dynamics of development: a methodological note. Third World Quarterly, 37(10), 1745-1767.

Castree N (2007) Labour geography: a work in progress. International Journal of Urban and Regional Research, 31(4), 853-862.

Castree N, Coe MN, Ward K and Samers M (2004) Spaces of Work: Global Capitalism and Geographies of Labour. London: Sage.

Çem M (2009) Dêrsim Merkezli Kürt Aleviliği: Etnisite, Dini Inanç, Kültür ve Direniş. İstanbul: Vate.

Coe NM and Jordhus-Lier DC (2011) Constrained agency? Re-evaluating the geographies of labour. Progress in Human Geography, 35(2), 211-233.

CounterCurrent (2011) Dam construction in Turkey and its impact on economic, cultural and social rights. Available at:

http://www2.ohchr.org/english/bodies/cescr/docs/ngos/JointReport_Turkey46.pdf (accessed 3 January 2017).

Das RJ (2012) From labor geography to class geography: reasserting the Marxist theory of class. Human Geography, 5(1), 19-35.

Dissard L (2017) From Shining Icons of Progress to Contested Infrastructures: "Damming" the Munzur Valley in Eastern Turkey. Available at:

https://laurentdissard.files.wordpress.com/2015/03/dissard-contested-munzur-nopic.pdf (accessed 14 January 2017).

DSİ (2009) 2010 yılı program bütçe toplantısı takdim raporu. Report, DSİ, IX. Bölge.

Ellem B (2003) New unionism in the old economy: community and collectivism in the Pilbara's mining towns. Journal of Industrial Relations, 45(4), 423-441.

Ellem B (2008) Contested communities: geo-histories of unionism. Journal of

Organizational Change Management, 21(4), 433-450.

Engels F (1892/2008) Socialism: Utopian and Scientific. New York: Casimo. 
EPDK (2017) Elektrik Piyasası Üretim Lisansları Veritabanı. Available at: http://lisans.epdk.org.tr/epvysweb/faces/pages/lisans/elektrikUretim/elektrikUretimOzetSorgula.xhtml (accessed 14 January 2017).

Ferguson S (2016) Intersectionality and social-reproduction feminisms: toward an integrative ontology. Historical Materialism, 24(2), 38-60.

FKA (2015) 2014 Y1lı Faaliyet Raporu. Report, Firat Development Agency, Malatya.

Governorship of Tunceli (2016b) Press statement. Available at:

http://www.tunceli.gov.tr/basin-aciklamasi-09092016. (accessed 3 January 2017).

Governorship of Tunceli (2015a) Press statement. Available at:

http://www.tunceli.gov.tr/basin-aciklamasil (accessed 3 January 2017).

Governorship of Tunceli (2015b) Tunceli ili 2014 yılı çevre durum raporu. Report, Tunceli Valiliği, Tunceli.

Governorship of Tunceli (2016a) Tunceli ili 2015 yılı çevre durum raporu. Report, Tunceli Valiliği, Tunceli.

Grand National Assembly of Turkey (2013) Uludere inceleme raporu. Report, Human Rights Inquiry Commission, Ankara.

Harvey D (2006a) The Limits to Capital. London: Verso.

Harvey D (2006b) Spaces of Global Capitalism: Towards a Theory of Uneven Geographical Development. London: Verso.

Herod A (1997) From a geography of labor to a labor geography: labor's spatial fix and the geography of capitalism. Antipode, 29(1), 1-31.

Herod A (2003) Workers, space, and labor geography. International Labor and WorkingClass History, 64, 112-138.

Herod A (2012) Workers as geographical actors. Labor History, 53(3), 335-353.

Johns R and Vural L (2000) Class, geography, and the consumerist turn: UNITE and the Stop Sweatshops Campaign. Environment and Planning A, 32(7), 1193-1213.

Jordhus-Lier D (2013) The geographies of community-oriented unionism: scales, targets, sites and domains of union renewal in South Africa and beyond. Transactions of the Institute of British Geographers, 38(1), 36-49.

Lier DC (2007) Places of work, scales of organising: a review of labour geography. Geography Compass, 1(4), 814-833. 
Massey D (1995) Spatial Divisions of Labor: Social Structures and the Geography of Production. New York: Routledge.

McCully P (2001) Silenced Rivers: The Ecology and Politics of Large Dams. London: Zed Books.

McDonald P, Mayes R and Pini B (2012). Mining work, family and community: a spatiallyoriented approach to the impact of the Ravensthorpe nickel mine closure in remote Australia. Journal of Industrial Relations, 54(1), 22-40.

McGrath-Champ S, Herod A and Rainnie A (2010) Handbook of Employment and Society: Working Space. Cheltenham: Edward Elgar.

Ministry of Development (2013) Illerin ve bölgelerin sosyo-ekonomik gelişmişlik sıralaması araştırması. Report, Kalkınma Bakanlığı, Ankara.

Ministry of Environment and Forestry (2009) 7/10663 sayll soru önergesine cevap. Ankara: Çevre ve Orman Bakanlığı.

Ministry of Forestry and Water Affairs (2012) 7/12536 sayılı soru önergesine cevap. Ankara: Orman ve Su İşleri Bakanlığı.

Ministry of Forestry and Water Affairs (2016) Ulusal biyolojik çeşitlilik envanter ve izleme projesi: Tunceli. Report, Orman ve Su İşleri Bakanlığı, Ankara.

Ministry of Interior (2016) Press statement: 2016/105. Available at:

https://www.icisleri.gov.tr/basin-aciklamasi171120163. (accessed 14 January 2017).

Ministry of Interior (2017) Number of active associations in Tunceli by years. Available at:

https://www.dernekler.gov.tr/en/home-links/Number-Active-Associations.aspx (accessed 14 January 2017).

Ministry of Justice (2013) 7/13848 sayll soru önergesine cevap. Ankara: Adalet Bakanlığı.

Official Gazette of the Republic of Turkey (1935) Tunceli vilâyetinin idaresi hakkında kanun. Available at:

https://www.tbmm.gov.tr/tutanaklar/KANUNLAR_KARARLAR/kanuntbmmc016/ka nuntbmmc016/kanuntbmmc01602884.pdf (accessed 12 January 2017).

Official Gazette of the Republic of Turkey (2017) 6 Ocak 2017 Tarihli ve 29940 Say1l

Resmi Gazete. Available at:

http://www.resmigazete.gov.tr/main.aspx?home=http://www.resmigazete.gov.tr/eskile r/2017/01/20170106m1.htm\&main=http://www.resmigazete.gov.tr/eskiler/2017/01/20 $\underline{170106 \mathrm{~m} 1 . \mathrm{htm}}$. (accessed 12 January 2017). 
Oseland SE, Haarstad H and Fløysand A (2012) Labor agency and the importance of the national scale: emergent aquaculture unionism in Chile. Political Geography, 31(2), 94-103.

Peck J (2003) Labor geographies: workers and the landscapes of capitalism. Annals of the Association of American Geographers, 93(2), 518-521.

Peck J (2017) Pluralizing labor geography. In: Clark GL, Feldman MP, Gertler MS and Wojcik D (eds) The New Oxford Handbook of Economic Geography. Oxford: Oxford University Press.

Provincial Directorate of Environment and Urbanization (2017) Tunceli'nin Ekonomik Yap1s1. Available at:

http://www.csb.gov.tr/iller/tunceli/index.php?Sayfa=sayfa\&Tur=webmenu\&Id=1698. (accessed 14 January 2017).

Ronayne M (2005) The Cultural and Environmental Impact of Large Dams in Southeast

Turkey. London: National University of Ireland, Galway and Kurdish Human Rights Project.

Selwyn B (2011) The political economy of class compromise: trade unions, capital-labour relations and development in North East Brazil. Antipode, 43(4), 1305-1329.

Storper M and Walker R (1989) The Capitalist Imperative: Territory, Technology, and Industrial Growth. New York: Basil Blackwell.

The Supreme Electoral Council (2017) Elections Database. Available at:

http://www.ysk.gov.tr/ysk/faces/Secimler?_adf.ctrl$\underline{\text { state }=k 31 \text { zeyisl } 31 \& \_ \text {afrLoop }=5798165793758932 \& \_ \text {afrWindowMode }=0 \& \& \text { afrWin }}$ dowId=k31zeyisl_55. (accessed 14 January 2017).

Tufts S (1998) Community unionism in Canada and labor's (re)organization of space. Antipode, 30(3), 227-250.

Tufts S and Savage L (2009) Labouring geography: negotiating scales, strategies and future directions. Geoforum, 40(6), 945-948.

Tunceli Chamber of Commerce and Industry (2017) Tunceli/Dersim'de Ekonomi Konferans1 Basın Bildirisi. Available at: http://www.tuncelitso.org.tr/tuncelidersimde-ekonomikonferansi-basin-bildirisi/. (accessed 14 January 2017).

Tunceli Industrialists and Entrepreneurs Association (2017) Presidential Statement. Available at: http://tusgid.com/details.jsf?id=2. (accessed 14 January 2017).

TÜRKONFED (2014) Bölgesel Kalkınmada Yerel Dinamikler: Tunceli Modeli ve 2023

Senaryoları. İstanbul: Fam Yayınları. 
Turkstat (2014) Seçilmiş göstergelerle Tunceli 2013. Report, Türkiye İstatistik Kurumu, Ankara.

Turkstat (2016a) Population of provinces, 2000-2016. Ankara: Turkiye Istatistik Kurumu.

Turkstat (2016b) Provincial in-migration, out-migration, net migration, rate of net migration, 1980-2015. Ankara: Turkiye Istatistik Kurumu.

Van Bruinessen MM (2000). Kürtlük, Türklük, Alevilik: Etnik ve Dinsel Kimlik Mücadeleleri. İstanbul: İletişim Yayınları.

Walsh J (2000) Organizing the scale of labor regulation in the United States: service-sector activism in the city. Environment and Planning A, 32(9), 1593-1610.

Wills J (2008) Mapping class and its political possibilities. Antipode, 40(1), 25-30.

World Commission on Dams (2000) Dams and development: a new framework for decisionmaking. London: Earthscan.

Wright EO (2000) Working-class power, capitalist-class interests, and class compromise. American Journal of Sociology, 105(4), 957-1002. 